Sains Malaysiana 50(12)(2021): 3659-3666

http://doi.org/10.17576/jsm-2021-5012-16

\title{
Low-frequency Electrical Stimulation Combined with Preventative Pelvic Floor Muscle Exercises and Knowledge-Attitude-Practice Model in Women with Urinary Retention after a Pelvic Surgery \\ (Rangsangan Elektrik Frekuensi Rendah yang Digabung dengan Latihan Pencegahan Otot Lantai Pelvis dan Model Pengetahuan-Sikap-Amalan pada Wanita dengan Pengekalan Air Kencing selepas Pembedahan Pelvis)
}

Hong LiU, Lixin Guo, Zhichen Kang, JiAngchun Zhang, Zhongliang LiU, TAiyuan LiU, Wei LiU \& Fuling QU*

\section{ABSTRACT}

This study was to explore the efficacy of low-frequency electrical stimulation (LFES) combined with preventative pelvic floor muscle exercises (PPFME) and knowledge-attitude-practice model (KAP model) in women with urinary retention (UR) after a pelvic surgery and the effect on quality of life (QOL). The clinical data of 153 women hospitalized with UR after a pelvic surgery from January 2015 to June 2019 were retrospectively analyzed and divided into the Control Group (CG, $n=45, L F E S+P P F M E)$ and the Study Group (SG, n=108, LFES+PPFME+KAP model) according to the different treatment methods. Following indicators were compared between the two groups: clinical efficacy, time to first urination, urine output, rate of extubation in $3 D$, rate of repeated intubation, urodynamic indicators before and after treatment, postvoid residual (PVR), bladder compliance (BC), maximal flow rate ( $Q$-max), pressure of detrusor at PdetQ-max (Pdet-Q-max), changes in QOL, incidence of urinary tract infection, and length of stay (LOS). Compared to CG, $S G$ showed higher overall response rate (ORR) and rate of extubation in $3 D$, shorter time to first urination, higher urine output, lower rate of repeated intubation and incidence of urinary tract infection, and shorter $\operatorname{LOS}(P<0.05)$; both groups achieved improvements in urodynamic indicators and QOL score after treatment $(P<0.05)$; the urodynamic indicators and QOL score in $S G$ were better than the CG'S $(P<0.05)$. LFES combined with PPFME and KAP model is effective in treating women with UR after a pelvic surgery by efficaciously improving patients' urination and QOL.

Keywords: KAP model; LFES; pelvic cavity; PPFME; QOL; UR

\section{ABSTRAK}

Kajian ini mengkaji keberkesanan rangsangan elektrik frekuensi rendah (LFES) yang digabungkan dengan latihan pencegahan otot lantai pelvis (PPFME) dan model pengetahuan-sikap-amalan (model KAP) pada wanita dengan pengekalan kencing (UR) selepas pembedahan pelvis dan kesan terhadap kualiti hidup (QOL). Data klinikal 153 wanita yang dimasukkan ke hospital dengan UR setelah pembedahan pelvis dari Januari 2015 hingga Jun 2019 dianalisis secara retrospektif dan dibahagikan kepada Kumpulan Kawalan (CG, $n=45$, LFES + PPFME) dan Kumpulan Kajian $(S G, n=108$, Model LFES + PPFME + KAP) mengikut kaedah rawatan yang berbeza. Petunjuk berikut dibandingkan antara kedua-dua kumpulan: keberkesanan klinikal, masa kencing pertama, pengeluaran air kencing, kadar pemupukan dalam 3D, kadar intubasi berulang, petunjuk urodinamik sebelum dan selepas rawatan, residu pasca lompong (PVR), kepatuhan pundi kencing (BC), kadar aliran maksimum (Q-max), tekanan detrusor pada Pdet-Q-max (Pdet-Qmax)], perubahan QOL, kejadian jangkitan saluran kencing dan jangka masa tinggal (LOS). Berbanding dengan CG, $S G$ menunjukkan kadar tindak balas keseluruhan (ORR) dan kadar pemupukan dalam 3D yang lebih tinggi, masa yang lebih pendek hingga kencing pertama, pengeluaran air kencing yang lebih tinggi, kadar intubasi berulang dan kejadian jangkitan saluran kencing dan LOS yang lebih pendek ( $P<0.05)$; kedua-dua kumpulan mencapai peningkatan dalam petunjuk urodinamik dan skor QOL selepas rawatan $(P<0.05)$; petunjuk urodinamik dan skor QOL dalam SG lebih baik daripada CG $(P<0.05)$. LFES yang digabungkan dengan model PPFME dan KAP berkesan untuk merawat wanita dengan UR setelah pembedahan pelvis dengan berkesan meningkatkan kencing dan QOL pesakit.

Kata kunci: LFES; model KAP; PPFME; QOL; rongga pelvis; UR 


\section{INTRODUCTION}

Most of the gynecological surgeries are performed in the pelvic cavity. In addition to large incisions, these surgeries often involve the urethra, supporting tissues on pelvic floor as well as vessels and nerves in bladders and appendages. Patients are prone to various complications, including the commonest urinary retention (UR) (Kwaan et al. 2017). According to statistics, the incidence of UR in women after a pelvic surgery range between $2.9-44.61 \%$ approximately. Clinical manifestations include inability to urinate autonomously, bladder filling and distending pain in the lower abdomen. If effective treatment is not provided to recover the autonomous urination function of bladders, some patients may demand indwelling catheter again, which affects the prognosis and severely compromises their quality of life (QOL) (Wu et al. 2018). Presently, many treatments are available for women with UR after a pelvic surgery, including low-frequency electrical stimulation (LFES) (Mardani et al. 2018), pelvic floor muscle exercises (PFME) (Deffieux et al. 2015), psychotherapy, massage, acupuncture and moxibustion, which have definite effects (Meister et al. 2017). Knowledge-attitude-practice (KAP) is a model changing human's health-related behaviors. In the model, patients are guided to learn about the disease, build up faith, make changes and develop good habits and behaviors so as to enhance QOL (Zahiruddin et al. 2018). Based on this, the efficacy of LFES combined with preventative pelvic floor muscle exercises (PPFME) and KAP model in treating women with UR after a pelvic surgery and the effect on QOL are explored in this study.

\section{MATERIALS AND METHODS}

\section{GENERAL MATERIALS}

A retrospective analysis was conducted on the clinical data of 153 females with UR after a pelvic surgery in the Second Hospital of Jilin University from January 2015 to June 2019. All patients complied with the relevant diagnosis criteria in the Complications of Modern Surgery (Wu 2004) and underwent hysterectomy and pelvic lymphadenectomy. They did not urinate at 6-8 h after the surgery and were complicated with symptoms such as urgent urination and distending pain in the lower abdomen. Patients with UR of other causes, urinary tract infarction, chronic urinary tract infection or calculi in urinary tract were excluded. Of the 153 patients, 45 received conventional treatment were grouped as the Control Group (CG), and 108 received conventional treatment combined with KAP model were grouped as the Study Group (SG). This study had been approved with exemption from informed consent by the Ethics Committee of our hospital. This study is a retrospective study, which only collects the clinical data of patients and does not interfere with the treatment regimen of patients and will not bring physiological risks to patients. The researchers will make every effort to protect the information provided by patients from disclosure of personal privacy, and we have applied for exemption from informed consent.

\section{METHODS}

Conventional treatment: patients were treated by LFES and PPFME. LFES and PPFME were performed at $2 \mathrm{~d}$ after surgery. LFES: a LGT-2300S low-frequency electric pulse therapeutic device was used. Patients were instructed to lie on the back and relax the abdominal muscles. An electrode pad was attached to the Qugu on the abdomen while another one was affixed on sacrococcygeal plexus S3. Repeat frequency rate was set to $800 \mathrm{~Hz}$ and pulse width to 400 us. The stimulation was performed twice a day, and 20 to 30 min each time. Stimulation intensity was adjusted according to patients' tolerance and progressively increased. PPFME: (1) Muscle exercises of anus. Using idiodynamics, patients repeatedly tried to control and contract the vagina, urethra and musculi sphincter of anus for 25 to $30 \mathrm{~s}$. (2) Abdominal respiration training. Patients sat or stood, breathed out/in to relax/ contract the abdominal muscles for 5 to $6 \mathrm{~s}$ per time and 6 to 8 times a day. (3) Leg-raising. At the beginning, the two legs were raised alternatively, and one dropped while the other was high up in the air. Next, both legs were raised and dropped at the same time. The last step was treading. These exercises were taken 3 to 5 times a day, 15 to 20 min each time, and within the tolerance of patients. Overtraining was prohibited. KAP model: (1) Learn and develop faith. A guidance group of KAP model was established, including the director of the department and the professionally trained clinicians and nurses, and the publicity pamphlet of KAP model was formulated. The primary nurse for each patient conducted health education of UR-related knowledge and organized patients to discuss the hazards of UR and the importance of treatment. Health questionnaires were designed for the study to learn about patients' attitude toward recovery. Interventions were adopted for negative patients and factors affecting their faith, so as to build up faith in recovery. (2) PFME. It was the same as these for the CG. Medical staffs set examples and patients took exercises under their guidance. (3) Persistent guidance. A WeChat 
group was established and followed up twice a week by the principal nurse, in order to learn about the progress of recovery. If and when necessary, one-for-one guidance was provided and patients were encouraged to share experience in training. After discharge from the hospital, an outpatient medical record was established, and LFES plus PPFME was performed in the outpatient department every week, 5 times a week, and the health guidance of KAP model was provided by the primary physician in the outpatient department. Both groups were treated for 3 months. After surgery, the urinary catheter was removed according to the patient's recovery. When the patients wanted to urinate, the catheter balloon was loosened, and the catheter was removed with urination.

\section{OBSERVATION INDICATORS}

Clinical efficacy, time to first urination, urine output, rate of extubation in 3 days, rate of repeated intubation, urodynamic indicators before and after treatment [postvoid residual (PVR), bladder compliance (BC), maximal flow rate (Q-max) and pressure of detrusor at Pdet-Q-max (Pdet-Q-max)], changes in QOL, incidence of urinary tract infection and length of stay (LOS) were compared between the two groups. Clinical efficacy was judged according to following criteria: markedly effective if clinical symptoms disappear or are significantly relieved and $P V R \leq 100 \mathrm{~mL}$; effective if clinical symptoms are relieved and PVR ranges between 100 and $200 \mathrm{~mL}$; ineffective if clinical symptoms are not relieved or worsened and $P V R \geq 200 \mathrm{~mL}$ after at least 3 weeks of treatment. The overall response rate (ORR) is calculated by summing up the sum of markedly effective rate and effective rate. Before and after treatment, urodynamic indicators (PVR, BC, Q-max and Pdet-Q-max) were measured by a urine flow meter. Before the examination, the patient emptied the bowels and drank $300-500 \mathrm{~mL}$ of water. When the patient had a strong desire to urinate, the measuring instrument was placed under the seat hole for urination measurement. Before and after treatment, QLQ-C30 Questionnaire was used to evaluate the patients' QOL (Osman et al. 2018), including physical functions, social functions, psychological functions and roles. The score is positively correlated with the QOL.

\section{STATISTICAL ANALYSIS}

Statistical analysis was performed with SPSS 18.0. In case of numerical data expressed as Mean \pm Standard Deviation, intergroup differences were checked by $\mathrm{t}$ tests; in case of nominal data expressed as \%, comparison studies were carried out through $\mathrm{X}^{2}$ test for intergroup comparison. For all statistical comparisons, significance was defined as $\mathrm{P}<0.05$.

\section{RESULTS}

\section{GENERAL MATERIALS}

The two groups were not significantly different in average age, weight, primary diseases and educational background ( $\mathrm{P}>0.05$, Table 1$)$.

\section{CLINICAL EFFICACY}

The ORR was $91.67 \%$ in SG and $77.78 \%$ in $\mathrm{CG}(\mathrm{P}<0.05)$, suggesting the efficacy of LFES combined with PPFME and KAP model in treating women with UR after a pelvic surgery (Table 2).

\section{TIME TO FIRST URINATION AND URINE OUTPUT}

The time to first urination in the SG was $(41.68 \pm 10.35)$ min, significantly shorter than that of $(53.56 \pm 15.37)$ min in the $\mathrm{CG}$, showing statistical difference $(\mathrm{t}=5.565$, $\mathrm{P}<0.05)$. The urine output in the SG was $(587.36 \pm 67.52)$ $\mathrm{mL}$, significantly higher than that of $(453.81 \pm 34.25)$ $\mathrm{mL}$ in the $\mathrm{CG}$, showing statistical difference $(\mathrm{t}=16.197$, $\mathrm{P}<0.05)$. The results indicated that LFES combined with PPFME and KAP model in treating women with UR after a pelvic surgery could significantly shorten the time to first urination, increase the urine output and accelerate bladder recovery (Figure 1).

\section{RATE OF EXTUBATION IN 3D AND RATE OF REPEATED INTUBATION}

The rate of extubation in $3 \mathrm{D}$ was higher and the rate of repeated intubation was lower in the SG $(\mathrm{P}<0.05)$, indicating that LFES combined with PPFME and KAP model in treating women with UR after a pelvic surgery could significantly increase the rate of extubation, reduce the rate of repeated intubation and facilitate bladder recovery (Table 3 ).

\section{URODYNAMICS}

Before treatment, there was no significant difference in PVR, BC, Q-max and Pdet-Q-max between the two groups $(\mathrm{t} \geq 0.252, \mathrm{P}>0.05)$. After treatment, both groups gained improvements in PVR, BC, Q-max and Pdet-Qmax, which were more significant in the $S G(t \geq 9.815$, $\mathrm{P}<0.05$ ), suggesting that the LFES combined with PPFME and KAP model in treating women with UR after a pelvic surgery could significantly improve patients' bladder function (Figure 2). 
QOL

Before treatment, there was no significant difference in OQL between the two groups $(t \geq 0.193, P>0.05)$. Both groups' QOL scores were improved after treatment, and the improvement was more significant in $\mathrm{SG}$, showing statistically significant difference $(t \geq 3.155, P<0.05)$. This suggested that the LFES combined with PPFME and KAP model in treating women with UR after a pelvic surgery could significantly improve patients' QOL (Figure 3).

\section{INCIDENCE OF URINARY TRACT INFECTION AND LOS}

Compared to $\mathrm{CG}$, SG had lower incidence of urinary tract infection and shorter $\operatorname{LOS}(\mathrm{P}<0.05)$, indicating that the LFES combined with PPFME and KAP model in treating women with UR after a pelvic surgery could markedly reduce the incidence of urinary tract infection, shorten LOS and facilitate recovery (Table 4).

\section{DISCUSSION}

UR is a common complication in women after a pelvic surgery and its incidence after a cervical carcinoma surgery could be $5-70 \%$. A large number of pelvic nerves distribute in the cervical tissue, which may be damaged during a pelvic surgery. Furthermore, without supports from vagina, uterine appendages, ligaments and pelvic connective tissue, the bladders are prone to lose innervations and UR may develop (Wong et al. 2018). As a result, patients suffer more pains and difficulties in treatment. The risk of urinary tract infection (Mayumi et al. 2019; Net et al. 2018) will rise, disadvantaging the prognosis. As a common treatment of UR, indwelling catheter may lead to urinary tract infection while extubation difficulties are expected in some patients. Besides, repeated indwelling catheter may mechanically damage the urinary tract and therefore reduce patients' QOL (Carter-Brooks et al. 2018). Hence, early removing ureters to recovery patients' autonomous urination function and reducing the bladder PVR are the key points in clinical treatment of women with UR after a pelvic surgery at present.

In this study, LFES was combined with PPFME and KAP model to treat women with UR after a pelvic surgery. Results included higher ORR and rate of extubation in 3D, shorter time to first urination, higher urine output, lower rate of repeated intubation, and shorter LOS in SG; both groups have achieved improvements in PVR, BC, Q-max,
Pdet-Q-max and QOL, which were more significant in the SG. These findings were basically consistent with Song and Zhu (2019). At present, LFES is commonly adopted to treat women with UR after a pelvic surgery by promoting the urethra constrictor contraction and exerting effects on the bladder innervation nerves, for example, the sacral nerve. The purpose is to accelerate the recovery of Bladder muscles' muscular nerve functions (Hong et al. 2017; Zhang \& Li 2019). After a pelvic surgery, electrodes are placed on the abdomen of women with UR. On the one hand, it can enhance the pelvic floor reflection and the pelvic floor muscle group on the one hand; on the other hand, it can improve the control muscle groups of bladders and urethra as well as blood circulation in the pelvic tissues for furtherance in the recovery of autonomous urination function. In normal cases, people rely on the muscles of bladders, pelvic floor, vagina, and perineum dominated by the central nerve to urinate. Training these muscles could effectively improve the autonomous urination function (Goeppert et al. 2019; Zare et al. 2018). In addition, PFME helps effectively raise the pelvic floor muscle force generated by electrically stimulating the pelvic floor. The two methods exist side by side and play a part together in improving the pelvic floor muscle groups and facilitating the recovery of autonomous urination function. KAP is the collective name of knowledge, attitude and practice. It is so far a comparatively proved health behavior change theory (Keskinen et al. 2018; Moyo \& Rusinga 2017). Imbuing patients with relevant knowledge helps them to build up faith in recovery and a positive attitude toward PFME. Correct exercises promote the recovery of pelvic muscle functions. Meanwhile, understanding the hazards of UR can reinforce patients' faith in developing habits of exercise, which is more conducive to the above trainings, so as to better recover the bladder function, thereby alleviating clinical symptoms and improving QOL. In this study, the incidence of urinary tract infection in $\mathrm{CG}$ was as high as $15.56 \%$, which was significantly higher than that in SG. The reason may be that the implementation of KAP model can improve patients' cognition of diseases, treatment and nursing, correct their past wrong habits, enable patients to actively carry out pelvic floor muscle training, train their autonomous urination function, shorten the time of catheter indwelling, and reduce the incidence of urinary tract infection. 

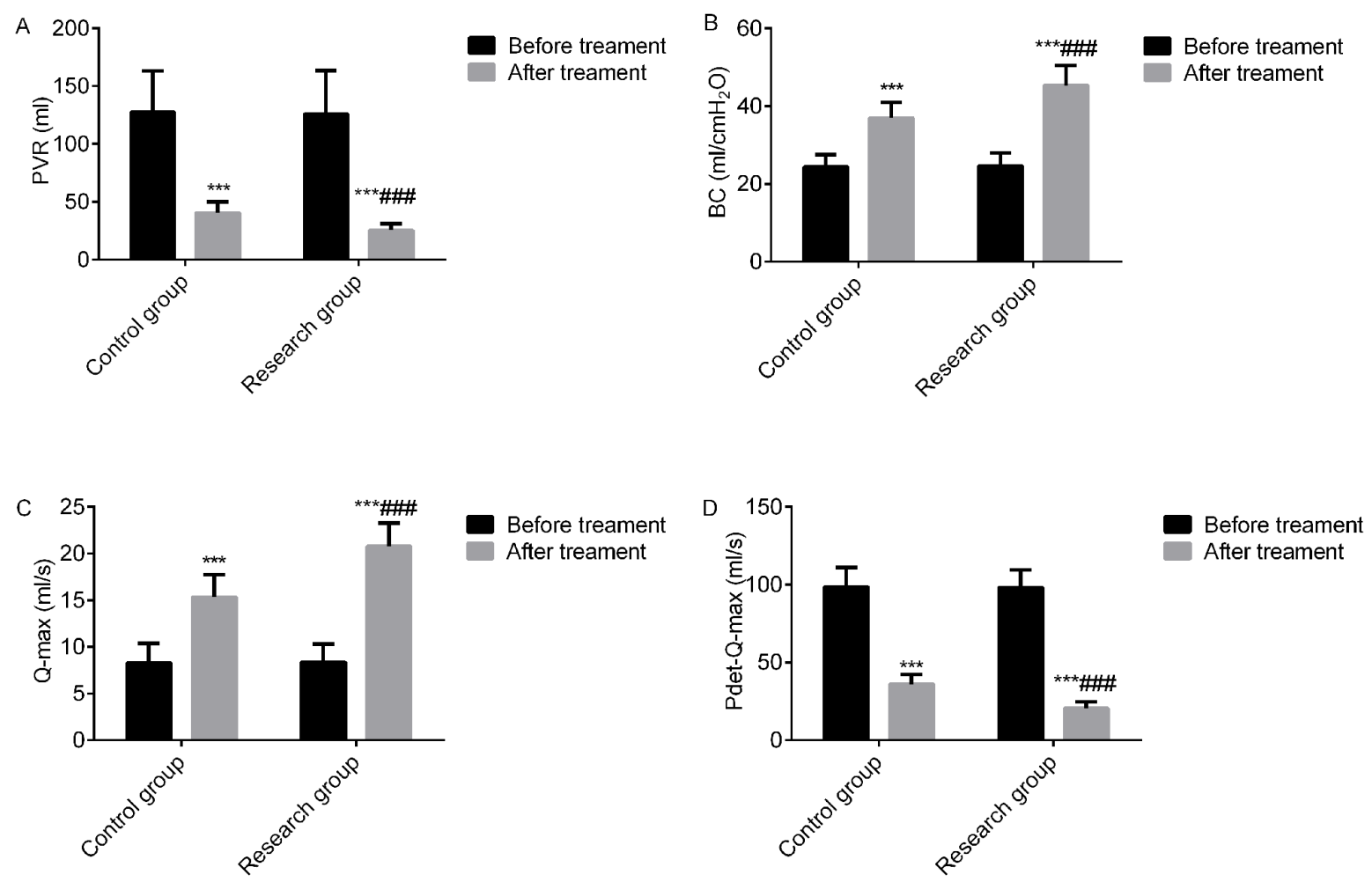

FIGURE 1. Intergroup comparison of time to first urination and urine output $\left(\bar{x}_{ \pm}\right)$

$$
\text { Note: }{ }^{* * * *} P<0.001 \text { vs. } C G
$$

A

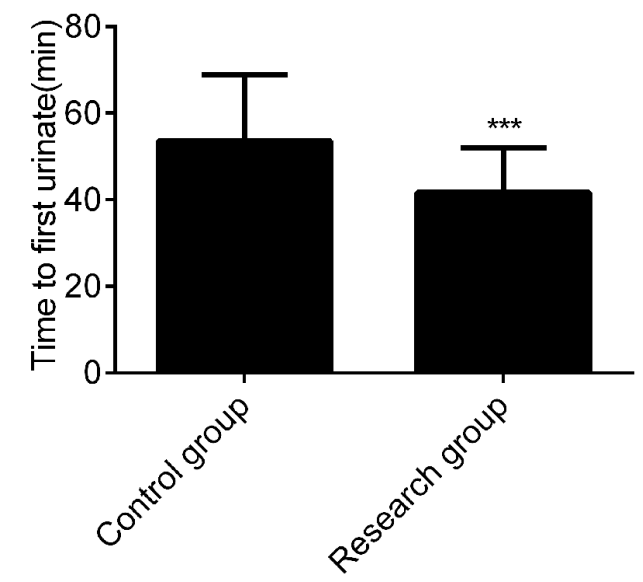

B

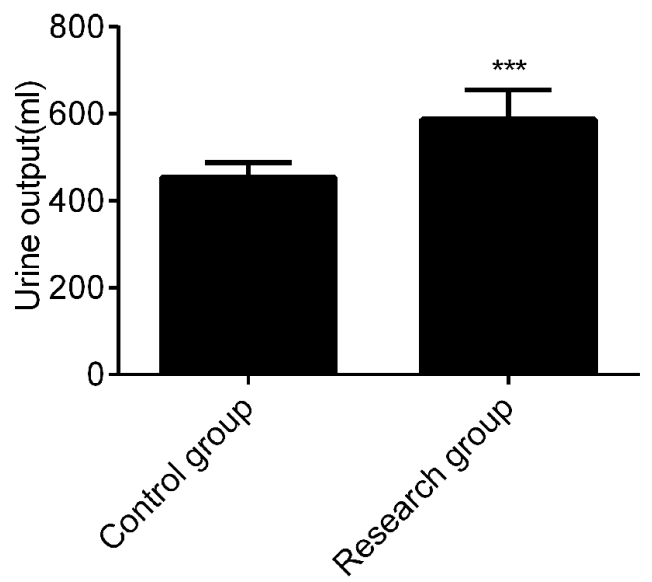

FIGURE 2. Intergroup comparison of urodynamics before and after treatment Note: ${ }^{* * *} P<0.05$ vs. before treatment; ${ }^{\# \#} P<0.001$ vs. $C G$ 

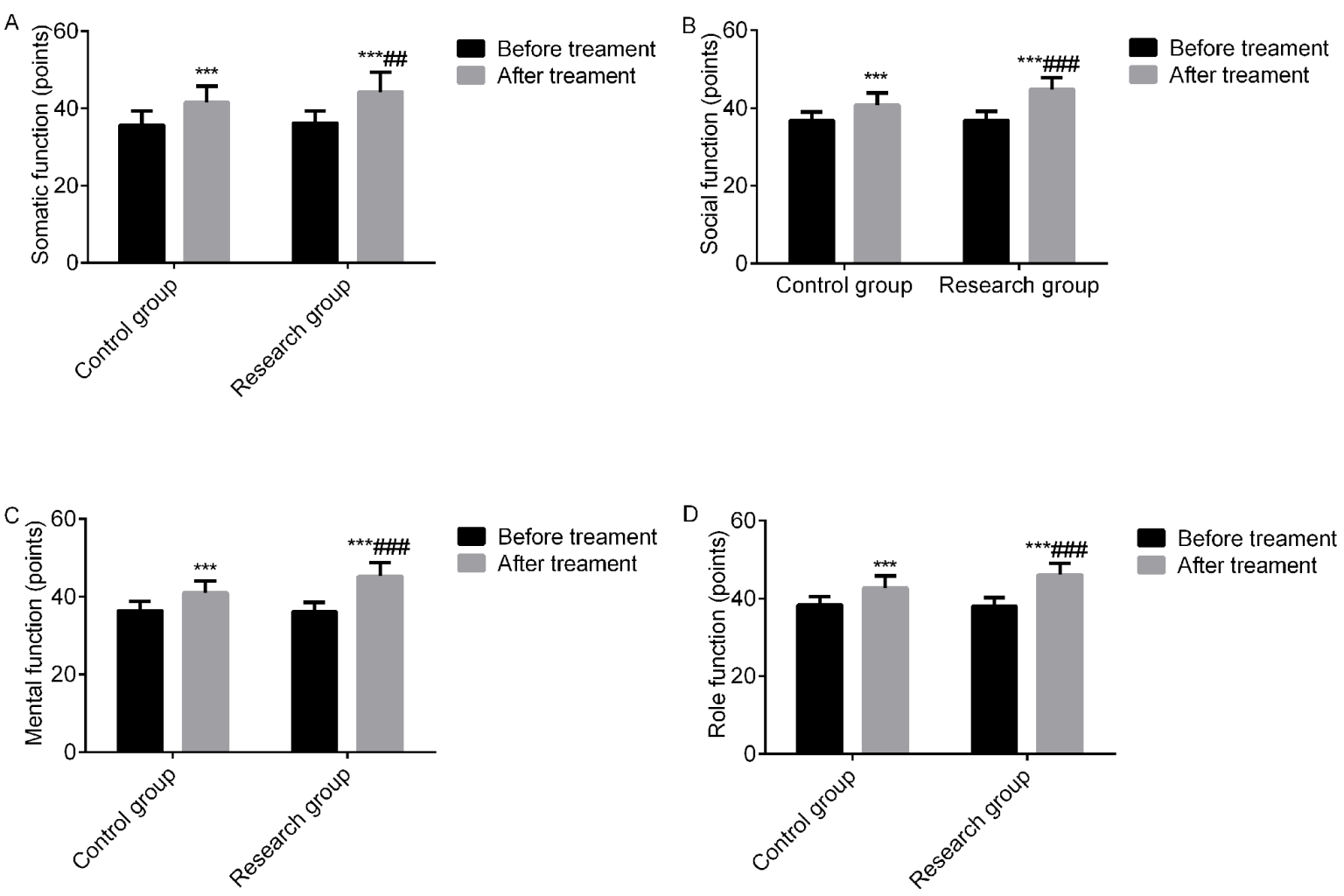

FIGURE 3. Intergroup comparison of QOL scores before and after treatment

Note: ${ }^{* * *} P<0.05$ vs. before treatment; ${ }^{\# \#} P<0.01$ and ${ }^{\# \# \#} P<0.001$ vs. CG

TABLE 1. Intergroup comparison of general materials $(\bar{x} \pm s)$

\begin{tabular}{|c|c|c|c|c|c|c|c|c|c|c|}
\hline \multirow[b]{2}{*}{ Group } & \multirow[b]{2}{*}{$\begin{array}{c}\text { Average age } \\
(\bar{x} \pm s, \mathrm{y})\end{array}$} & \multirow[b]{2}{*}{$\begin{array}{c}\text { Average } \\
\text { weight } \\
(\bar{x} \pm s, \mathrm{~kg})\end{array}$} & \multicolumn{2}{|c|}{ Primary disease } & \multicolumn{2}{|c|}{$\begin{array}{c}\text { Educational background } \\
(\%)\end{array}$} & \multirow[b]{2}{*}{$\begin{array}{c}\text { Time of } \\
\text { surgery }(\min )\end{array}$} & \multirow[b]{2}{*}{$\begin{array}{l}\text { Intraoperative } \\
\text { blood loss } \\
(\mathrm{mL})\end{array}$} & \multirow[b]{2}{*}{$\begin{array}{l}\text { Number } \\
\text { of lymph } \\
\text { nodes } \\
\text { removed }\end{array}$} & \multirow[b]{2}{*}{$\begin{array}{l}\text { Preoperative } \\
\text { diabetes } \\
\text { mellitus } \\
\text { (case) }\end{array}$} \\
\hline & & & $\begin{array}{l}\text { Cervical } \\
\text { carcinoma }\end{array}$ & $\begin{array}{c}\text { Ovarian } \\
\text { cancer }\end{array}$ & $\begin{array}{c}\text { Junior } \\
\text { middle } \\
\text { school, } \\
\text { primary } \\
\text { school and } \\
\text { illiterate }\end{array}$ & $\begin{array}{l}\text { Senior high } \\
\text { school, } \\
\text { college and } \\
\text { university }\end{array}$ & & & & \\
\hline $\mathrm{CG}(\mathrm{n}=45)$ & $51.36 \pm 6.35$ & $61.74 \pm 8.37$ & $29(64.44)$ & $16(35.56)$ & $21(46.67)$ & $24(53.33)$ & $158.36 \pm 35.14$ & $284.50 \pm 49.57$ & $21.36 \pm 2.84$ & $11(24.44)$ \\
\hline$S G(n=108)$ & $50.87 \pm 7.24$ & $61.24 \pm 9.06$ & $78(72.22)$ & $30(27.78)$ & $57(52.78)$ & $51(47.22)$ & $157.29 \pm 38.71$ & $286.14 \pm 54.18$ & $22.04 \pm 3.14$ & $25(23.15)$ \\
\hline$t / \chi^{2}$ & 0.395 & 0.318 & \multicolumn{2}{|c|}{0.914} & \multicolumn{2}{|c|}{0.475} & 0.160 & 0.175 & 1.254 & 0.030 \\
\hline$P$ & 0.693 & 0.751 & \multicolumn{2}{|c|}{0.339} & \multicolumn{2}{|c|}{0.491} & 0.873 & 0.862 & 0.212 & 0.863 \\
\hline
\end{tabular}

TABLE 2. Intergroup comparison of clinical efficacy [n (\%)]

\begin{tabular}{lcccc}
\hline Group & Marked effective & Effective & Ineffective & ORR \\
\hline $\mathrm{CG}(\mathrm{n}=45)$ & $19(42.22)$ & $16(35.56)$ & $10(22.22)$ & $35(77.78)$ \\
$\mathrm{SG}(\mathrm{n}=108)$ & $62(57.41)$ & $37(34.26)$ & $9(8.33)$ & $99(91.67)$ \\
$\chi^{2}$ & - & - & - & 5.634 \\
$P$ & - & - & - & 0.018 \\
\hline
\end{tabular}


TABLE 3. Intergroup comparison of rate of extubation in $3 \mathrm{D}$ and rate of repeated intubation (n (\%))

\begin{tabular}{lcc}
\hline Group & Rate of extubation in 3d & Rate of repeated intubation \\
\hline $\mathrm{CG}(\mathrm{n}=45)$ & $25(55.56)$ & $9(20.00)$ \\
$\mathrm{SG}(\mathrm{n}=108)$ & $78(72.22)$ & $6(5.56)$ \\
$\chi^{2}$ & 5.060 & 5.950 \\
$P$ & 0.025 & 0.015 \\
\hline
\end{tabular}

TABLE 4. Intergroup comparison of incidence of urinary tract infection and LOS

\begin{tabular}{lcc}
\hline Group & Urinary tract infection $(\%)$ & $\operatorname{LOS}(\bar{x} \pm S, \mathrm{~d})$ \\
\hline $\mathrm{CG}(\mathrm{n}=45)$ & $7(15.56)$ & $18.75 \pm 2.84$ \\
$\mathrm{SG}(\mathrm{n}=108)$ & $2(1.85)$ & $14.15 \pm 2.14$ \\
$\chi^{2} / t$ & 8.442 & 10.960 \\
$P$ & 0.004 & 0.000 \\
\hline
\end{tabular}

\section{CONCLUSION}

In conclusion, this study has established the efficacy of LFES combined with PPFME and KAP model in treating women with UR after a pelvic surgery, including effectively improving urination, shortening LOS and increasing QOL. However, the limited samples may lead to biased results. Future clinical studies shall be more large-scale and intensive.

\section{REFERENCES}

Carter-Brooks, C.M., Zyczynski, H.M., Moalli, P.A., Brodeur, P.G. \& Shepherd, J.P. 2018. Early catheter removal after pelvic floor reconstructive surgery: A randomized trial. Int Urogynecol. J. 29(8): 1203-1212.

Deffieux, X., Vieillefosse, S., Billecocq, S., Battut, A., Nizard, J., Coulm, B. \& Thubert, T.. 2015. Postpartum pelvic floor muscle training and abdominal rehabilitation: Guidelines. $J$. Gynecol. Obstet. Biol. Reprod. (Paris) 44(10): 1141-1146.

Goeppert, B., Roessler, S., Renner, M., Loeffler, M., Singer, S., Rausch, M., Albrecht, T., Mehrabi, A., Vogel, M.N., Pathil, A. \& Czink, E. 2019. Low frequency of mismatch repair deficiency in gallbladder cancer. Diagn. Pathol. 14(1): 36.

Hong, J.M., Kim, K.H., Lee, H.J., Kwon, J.Y., Kim, H.K., Kim, H.J., Cho, A.R., Do, W.S. \& Kim, H.S. 2017. Epidural dexamethasone influences postoperative analgesia after major abdominal surgery. Pain Physician 20(4): 261-269.

Keskinen, H., Helenius, L., Pajulo, O. \& Helenius, I.J. 2018. Postoperative urinary retention or difficulties to empty the bladder in young patients undergoing posterior spinal fusion for adolescent idiopathic scoliosis. J. Pediatr. Surg. 53(8): 1542-1546.

Kwaan, M.R., Fan, Y., Jarosek, S. \& Elliott, S.P. 2017. Long-term risk of urinary adverse events in curatively treated patients with rectal cancer: A population-based analysis. Dis. Colon. Rectum. 60(7): 682-690.

Mardani, P., Oryan, S., Sarihi, A., Komaki, A., Shojaei, A., Dehghan, S. \& Mirnajafi-Zadeh, J. 2018. ERK activation is required for the antiepileptogenic effect of low frequency electrical stimulation in kindled rats. Brain Res. Bull. 140: 132-139.

Mayumi, R., Murano, Y., Yokota, R., Nakao, A., Miyazaki, N., Hara, T., Mizutani, A., Hayashi, K., Sakurai, Y., Shoji, H. \& Nakazawa, T. 2019. Urinary angiotensinogen in pediatric urinary tract infection. Pediatr. Int. 61(7): 712-714.

Meister, F.A., Amygdalos, I., Neumann, U.P. \& Lurje, G. 2017. Rectal foreign body insertion as a rare cause of persistent lumbosacral plexus injury. Ann. R. Coll. Surg. Engl. 99(6): e191-e192.

Moyo, S. \& Rusinga, O. 2017. Contraceptives: Adolescents' knowledge, attitudes and practices. A case study of rural 
Mhondoro-Ngezi District, Zimbabwe. Afr. J. Reprod. Health 21(1): 49-63.

Net, P., Karnycheff, F., Vasse, M., Bourdain, F., Bonan, B. \& Lapergue, B. 2018. Urinary tract infection after acute stroke: Impact of indwelling urinary catheterization and assessment of catheter-use practices in French stroke centers. Rev. Neurol. (Paris) 174(3): 145-149.

Osman, N.I., Hillary, C.J., Mangera, A., Aldamanhoori, R., Inman, R.D. \& Chapple, C.R 2018. The midurethral fascial "sling on a string": An alternative to midurethral synthetic tapes in the era of mesh complications. Eur. Urol. 74(2): 191-196.

Song, J. \& Zhu, Y.T. 2019. Effects of systematic functional exercises combined with electric stimulation of pelvic floor nerves and muscles on female patients with urinary retention after a malignant tumor surgery. Laboratory Medicine and Clinic 16(6): 831-833.

Wong, M.C., Isaacson, K. \& Morris, S. 2018. Into the void: A review of postoperative urinary retention after minimally invasive gynecologic surgery. Curr. Opin. Obstet. Gynecol. 30(4): 260-266.

Wu, H., Qi, P., Dai, R., Li, Z. \& Feng, H. 2018. Urine retention as the first presentation of congenital absence of the sacrum: A case report of a rare clinical phenomenon. Medicine (Baltimore) 97(31): e11623.

Wu, M.C. 2004. Complications of Modern Surgery. Beijing: World Publishing Corporation.
Zahiruddin, W.M., Arifin, W.N., Mohd-Nazri, S., Sukeri, S., Zawaha, I., Bakar, R.A., Hamat, R.A., Malina, O., Jamaludin, T.Z.M.T., Pathman, A., Norazlin, I. Suhaila, B.S., Saudi, S.N.S., Abdullah, N.M., Nozmi, N., Zainuddin, A.W \& Aziah, D. 2018. Development and validation of a new knowledge, attitude, belief and practice questionnaire on leptospirosis in Malaysia. BMC Public Health 18(1): 331.

Zare, A., Jahanshahi, A., Meriaux, C., Steinbusch, H.W. \& van Koeveringe, G.A. 2018. Glutamatergic cells in the periaqueductal gray matter mediate sensory inputs after bladder stimulation in freely moving rats. Int. J. Urol. 25(6): 621-626.

Zhang, L.Y. \& Li, J. 2019. Evaluating the effectiveness of Chinese QOL scale for patients with gastrointestinal neuroendocrine tumors. Journal of Nursing Science 13: 27-30.

Hong Liu, Lixin Guo, Zhichen Kang, Jiangchun Zhang, Zhongliang Liu, Wei Liu \& Fuling Qu*

The Second Hospital, Jilin University

China

Taiyuan Liu

The Second Affiliated Hospital of Dalian Medical University China

*Corresponding author; email: linglingfu@yeah.net

Received: 21 December 2020

Accepted: 22 March 2021 